\title{
Experimental Investigation of the Deformation Characteristics of Tianjin Clays under Coupled Dynamic Stress and Seepage Fields
}

\author{
Huayang Lei, ${ }^{1,2}$ Shuangxi Feng, ${ }^{1}$ Rui Jia $\mathbb{D}^{1}{ }^{1}$ and Mingjing Jiang ${ }^{1}$ \\ ${ }^{1}$ Department of Civil Engineering, Tianjin University, Tianjin 300072, China \\ ${ }^{2}$ Key Laboratory of Coast Civil Structure Safety of the Ministry of Education, Tianjin University, Tianjin 300072, China \\ Correspondence should be addressed to Rui Jia; jiarui@tju.edu.cn
}

Received 3 January 2019; Revised 21 March 2019; Accepted 27 March 2019; Published 30 April 2019

Academic Editor: Hossein Moayedi

Copyright (c) 2019 Huayang Lei et al. This is an open access article distributed under the Creative Commons Attribution License, which permits unrestricted use, distribution, and reproduction in any medium, provided the original work is properly cited.

\begin{abstract}
The causes, prevention, and control of clay disasters are of great concern in practical engineering applications. Recently, due to unprecedented economic development, increasing numbers of tunnels and subgrades of tidal flat areas have been built in Tianjin, China. Soft soil ground not only bears the vibration load during operation and construction but also receives seepage effects caused by the bursting of pipelines and variations in groundwater levels. Under the coupling action of dynamic and seepage loads, large settlement can occur in soft soil since the deformation is related to both cyclic stress and seepage. Therefore, it is significant to understand the dynamic deformation characteristics of soil to ensure the safety of engineering applications. In this study, a series of laboratory cyclic triaxial tests were conducted to study the deformation behaviours of Tianjin clays under coupled cyclic stress and seepage fields. To simulate the seepage field, water pressure is applied at the bottom of the specimen, and the water can be drained from the top of the specimen to form a head difference in the specimen during the tests. The effects of the seepage pressure, cyclic stress ratio (CSR), and a number of cycles $(N)$ on the hydraulic conductivity, axial deformation, hysteresis curve and dynamic modulus of Tianjin clays were systematically investigated. The laboratory results show that the hydraulic conductivity $(k)$ decreases with the increasing seepage pressure, CSR, and $N$, and its range is from $4.6 \times 10^{-8} \mathrm{~cm} / \mathrm{s}$ to $7.4 \times 10^{-8} \mathrm{~cm} / \mathrm{s}$. The axial deformation of the soil increases with increasing CSR and seepage pressure. With an applied water pressure of $150 \mathrm{kPa}$ at the bottom of the specimen and a CSR of 0.3 , the maximum cumulative plastic strain reaches $4.78 \%$, increasing by $53.2 \%$ compared with a CSR of 0.1 . The hysteresis curve gradually becomes denser or thinner with increasing CSR and $N$; the hysteretic curve tends to a straight line for $N$ of 5,000. The dynamic modulus increases with increasing $N$ and depends on the CSR and seepage pressure. Empirical equations are suggested for calculating the dynamic modulus with different CSR values and seepage pressures. The results of this study can provide reference parameters for the construction and design of tunnels and subgrades of tidal flat areas in clay strata under the influence of water environments.
\end{abstract}

\section{Introduction}

With the unprecedented increase in urbanization and largescale infrastructure construction, infrastructure integrity is crucial for the sustainable socioeconomic development of coastal cities in China. For construction on soft soil, which is distinct from other regular soils in that it exhibits poor engineering properties such as high natural water content, high compressibility, high void ratio, low bearing capacity, and low permeability, the potential for ground subsidence is of major concern $[1,2]$. Mechanical vibration, traffic loads (such as high-speed trains or subway trains), wave loads, and other dynamic stress coupled with seepage caused by rainfall, groundwater, and other factors are primarily responsible for long-term soft ground subsidence [3, 4]. For example, in the past 20 years, Tianjin city in China has taken leadership in large-scale tunnel engineering at the heart of the city and subgrade engineering of the flat tidal area in the clay strata. However, on the one hand, during the construction and operation of the tunnel, the soft soil foundation will bear the dynamic construction load and the train vibration load [5]. In addition, there are many groundwater 
pipes on the ground and underground in the city centre. Because of the construction disturbance and train vibration, the water pipes may break. Once the water pipes break, water will begin gushing into the tunnel, causing tunnel collapse and ground subsidence, as well as other disasters, as shown in Figure 1(a) [6]. On the other hand, in tidal flat areas, high and low tides occur daily, and the subgrade must bear the seepage load, construction disturbance, and traffic load caused by subgrade construction and train operations. Research has shown that subgrade settlement deformation is extremely large, and settlement control struggles to meet engineering requirements, as shown in Figure 1(b) [7]. To mitigate the risk of ground subsidence and ensure sustainable infrastructure, it is necessary to advance research in understanding the mechanisms of the long-term deformation of soft clay and predict the settlement of postconstruction soft soil foundations under multifield coupling conditions.

Most prior research has focused on the dynamic and permeability characteristics of soft soil. With respect to the dynamic response of soft clay, many scholars have concentrated on the cyclic deformation and deformation mechanism of soils under cyclic loading considering many factors, such as the waveform, number of cycles $(N)$, vibration frequency $(f)$, cyclic stress ratio (CSR), and confining pressure $(\sigma)[8,9]$. Zhao et al. conducted cyclic triaxial tests on soft marine clay and revealed that increased cyclic stress levels and the application of the initial deviatoric stress accelerate the attenuation of the dynamic modulus [10]. Shen et al. carried out a series of undrained shear tests using a hollow cylinder apparatus and demonstrated the variation in dynamic deformation due to vibrations under different dynamic stress ratios [11]. Pandya and Sachan studied the effect of load repetition on the dynamic characteristics of saturated Ahmedabad cohesive soil and investigated the effects of the number of cycles and the CSR on the undrained deformation behaviour [12]. A series of loading tests were conducted by Miao et al. on soft soil specimens under different confining pressures. Test results showed that the confining pressure has a significant influence on the drainage behaviour of soft marine clay specimens and that the drainage volume decreases linearly with increasing confining pressure [13]. The effect of the vibration frequency on the dynamic properties of clay remains controversial. Various published works have indicated that the vibration frequency has little or no influence on cyclic deformation $[14,15]$. Yasuhara et al. showed that a vibration frequency of 1-2 Hz has only a slight effect on the deformation of soft clays for a given stress level [16]. Cyclic strain-controlled tests on normally consolidated kaolinite clay were conducted by Mortezaie and Vucetic, who determined that soil can experience higher pore water pressure under low-frequency cyclic loading for a certain number of cycles [17]. However, others have argued that vibration frequencies have a notable impact on the dynamic properties of soft clay. Wang revealed that lower vibration frequencies have a considerable effect on the accelerated creep behaviours of marine clay from a microstructural perspective [18]. Lei et al. compared the dynamic deformation characteristics of soft marine soil with different vibration frequencies and showed that the lower the vibration frequency is, the greater the dynamic deformation is $[19,20]$.

A large number of practical monitoring data reveal that most geological disasters and geotechnical engineering failures are related to water in the soil. When seepage occurs, many unfavourable factors may arise due to an increased seepage force. Moreover, many researchers have noticed that the seepage of soft clay deviates from Darcy's law, which is different from the permeability of sand. Many researchers have investigated the seepage behaviour of various clays $[21,22]$. Sun and $\mathrm{Xu}$ proposed that the hydraulic conductivity of undisturbed clays under dynamic loading is considerably higher than that of reconstituted clays and suggested that the influence of the void ratio and structural behaviours should be considered when determining the permeability of saturated soft clay [23]. Bayesteha and Mirghasemi analysed the coefficient of permeability of active clays and their porosity and tortuosity and demonstrated that the coefficient of permeability decreased as the void ratio decreased [24]. Arpan and Sujit constructed a threedimensional (3D) consolidation apparatus to research the differences in horizontal and vertical hydraulic conductivity of clay. The authors showed that the horizontal permeability is higher than the vertical permeability, and the permeability decreases with increasing vertical stresses [25]. Muddle and Briggs used X-ray computed tomography (XCT) to study the macropore structure and permeability of clay fill samples from a historic clay fill earthwork. They suggested that the macropore length has a greater influence on the saturated hydraulic conductivity than the total porosity based on their laboratory-scale samples [26].

Although many researchers have focused on the seepage and cyclic deformation characteristics of soft soils, seepage and dynamic stress analyses of soft clays are typically conducted separately, and there are few experimental studies on the cyclic deformation of soft clay under coupled dynamic stress and seepage fields. Jia studied the long-term hydromechanical coupled behaviour of Belgium Boom clay to explain the effect of seepage on deformation [27]. Zhong et al. used a 3D simulation technique, the volume of fluid (VOF) method, and the Navier-Stokes (N-S) equations to investigate the seepage of clay coupled with cyclic stress [28].

With lessons learnt from extensive relevant projects and advanced research, the deformation of soil under dynamic loads and seepage loads has been identified as the culprit for the failure of soft clay ground. Research has shown that most of these problems occur without considering the deformation characteristics of a soft clay foundation under dynamic loads, resulting in an excessive settlement that affects the normal use of tunnels and subgrades of tidal flat areas. Therefore, studying the cyclic deformation characteristics of soil under coupled cyclic stress and seepage fields is important for geotechnical surveys and civil engineering design and is urgently needed to meet the requirements of engineering practices.

In this study, the deformation characteristics of Tianjin clays under coupled dynamic stress and seepage fields were studied. First, the variability in hydraulic conductivity of 


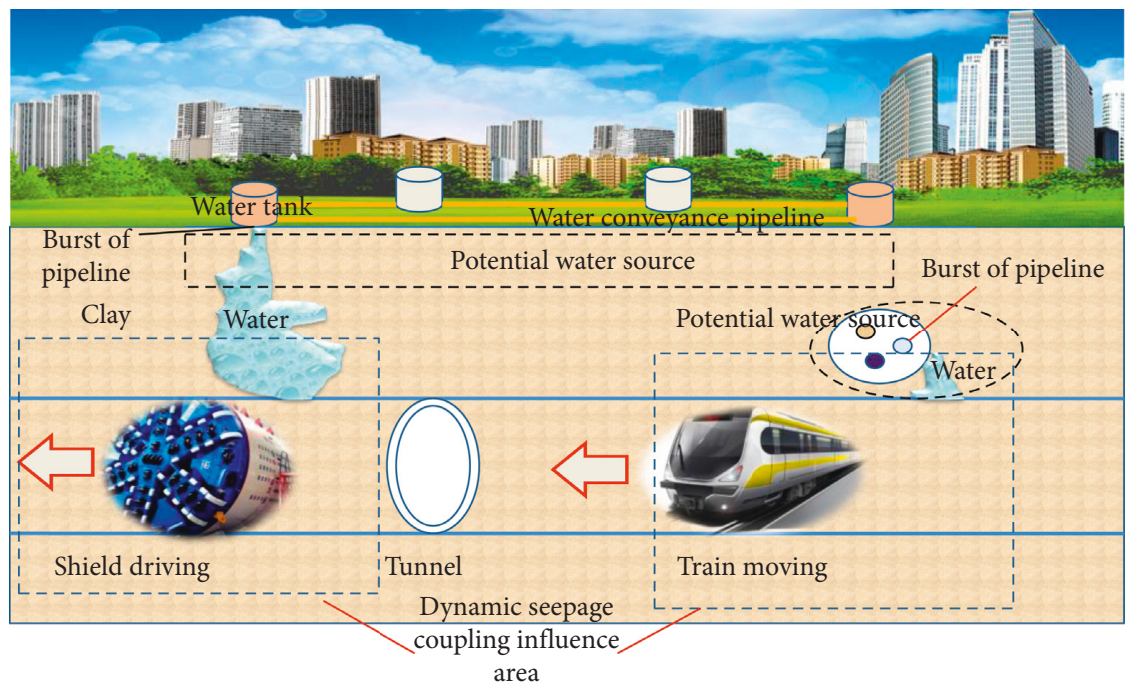

(a)

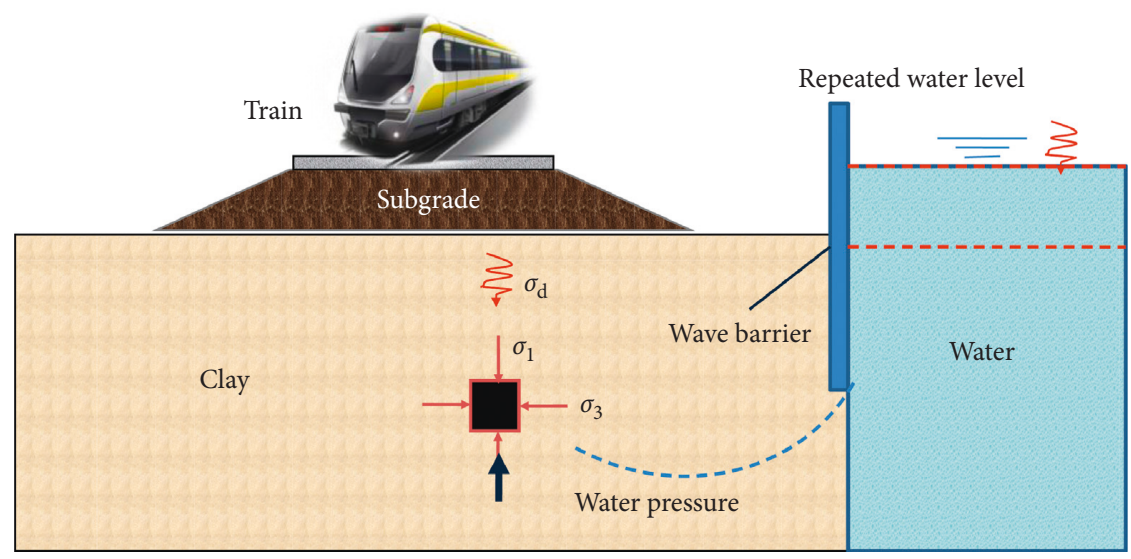

(b)

FIgURE 1: Engineering for coupled dynamic and seepage fields: (a) tunnel engineering; (b) subgrade engineering.

Tianjin clays under coupled dynamic stress and seepage fields was investigated. Then, the effects of the seepage pressure, CSR, and $N$ on the axial deformation of Tianjin clays under coupled dynamic stress and seepage fields were systematically investigated. Finally, the effects of the CSR and seepage pressure on the hysteretic characteristics and dynamic modulus of Tianjin clays subjected to coupled dynamic stress and seepage fields were identified. The test results are useful for evaluating the cyclic deformation properties of Tianjin clays under coupled cyclic stress and seepage fields. The test method and results could also serve as a reference for future research on the coupled dynamicseepage response of soft clays.

\section{Experimental Program}

2.1. Soil Samples. The Tianjin clay samples were obtained from depths of $8-15 \mathrm{~m}$ below the ground surface at a construction site located within the core functional area of the Tianjin Binhai New Area. Shelby tubes with an internal diameter of $9.8 \mathrm{~cm}$ and a tapered end of 6 degrees were used to collect soil samples and reduce sampling disturbance. The length of the tubes was $50 \mathrm{~cm}$, and the wall thickness was $0.2 \mathrm{~cm}$.

Basic physical indexes of the soil samples were obtained via laboratory soil testing according to the local standard "Specification of soil test" (SL237-1-1999) [29]. The samples used in the study had a water content ranging from $40 \%$ to $52.5 \%$. The liquid limit was measured using the Casagrande method [30], and the values ranged from $51.7 \%$ to $70.15 \%$. The plastic limit was determined using the thread-rolling method, and the values ranged from $25.3 \%$ to $27.4 \%$. The void ratios and the initial densities of the soil samples ranged from approximately 1.11 to 1.355 and from 1.61 to $1.79 \mathrm{~g} /$ $\mathrm{cm}^{3}$, respectively, as shown in Table 1 .

Figure 2 shows the plasticity chart for the clay samples. The data points lie between the A line and $\mathrm{U}$ line, and the liquid limits are greater than $50 \%$. According to the Unified Soil Classification System (USCS), all the tested samples from the Tianjin marine deposits were high-plasticity clay $(\mathrm{CH})$.

The hydrometer test was performed in a sedimentation cylinder with $50 \mathrm{~g}$ of the oven-dried sample to obtain the particle-size distribution of Tianjin clays. The height of the 
Table 1: Primary index properties of the tested Tianjin clays.

\begin{tabular}{|c|c|c|c|c|c|c|c|c|c|}
\hline No. & $\begin{array}{l}\text { Depth } \\
(\mathrm{m})\end{array}$ & $\begin{array}{c}\text { Water } \\
\text { content, } \omega \\
(\%)\end{array}$ & $\begin{array}{c}\text { Initial density, } \\
\rho_{0}\left(\mathrm{~g} / \mathrm{cm}^{3}\right)\end{array}$ & $\begin{array}{l}\text { Initial void } \\
\text { ratio, } e_{0}\end{array}$ & $\begin{array}{l}\text { Liquid limit, } \\
\omega_{\mathrm{L}}(\%)\end{array}$ & $\begin{array}{c}\text { Plastic limit, } \\
\omega_{\mathrm{P}}(\%)\end{array}$ & $\begin{array}{c}\text { Cohesive } \\
\text { force, } c(\mathrm{kPa})\end{array}$ & $\begin{array}{l}\text { Internal friction } \\
\text { angle, } \varphi\left(^{\circ}\right)\end{array}$ & $\begin{array}{c}\text { Compression } \\
\text { index, } C_{\mathrm{c}}\end{array}$ \\
\hline 1 & 8.1 & 52.5 & 1.61 & 1.355 & 70.15 & 27.4 & 2.0 & $12.2 \sim 13.6$ & 0.51 \\
\hline 2 & 8.3 & 50.2 & 1.62 & 1.355 & 70.1 & 27.3 & 2.1 & 13.1 & 0.50 \\
\hline 3 & 8.5 & 52.5 & 1.61 & 1.34 & 66.2 & 27.2 & 2.0 & 13.3 & 0.48 \\
\hline 4 & 8.6 & 51.9 & 1.64 & 1.34 & 68.2 & 27.2 & 2.5 & 12.8 & 0.48 \\
\hline 5 & 8.9 & 49.9 & 1.63 & 1.32 & 65.7 & 27.1 & 2.6 & 13.6 & 0.46 \\
\hline 6 & 9.1 & 48.7 & 1.65 & 1.28 & 60.1 & 27.2 & 2.6 & 13.5 & 0.47 \\
\hline 7 & 9.4 & 48.7 & 1.63 & 1.29 & 61.4 & 26.9 & 2.9 & 12.2 & 0.45 \\
\hline 8 & 9.7 & 47.8 & 1.62 & 1.26 & 62.5 & 26.9 & 2.6 & 12.8 & 0.45 \\
\hline 9 & 9.9 & 47.5 & 1.66 & 1.14 & 66.3 & 26.4 & 3.2 & 12.7 & 0.43 \\
\hline 10 & 10.3 & 46.2 & 1.65 & 1.25 & 61.2 & 26.4 & 3.6 & 12.9 & 0.44 \\
\hline 11 & 10.5 & 46.8 & 1.64 & 1.28 & 63.3 & 26.6 & 3.6 & 13.2 & 0.42 \\
\hline 12 & 10.6 & 46.7 & 1.68 & 1.11 & 62.8 & 26.4 & 3.9 & 13.2 & 0.39 \\
\hline 13 & 10.8 & 46.5 & 1.67 & 1.28 & 60.1 & 26.1 & 4.1 & 13.6 & 0.39 \\
\hline 14 & 10.9 & 46.0 & 1.72 & 1.28 & 58.9 & 26.1 & 4.2 & 12.9 & 0.35 \\
\hline 15 & 11.1 & 46.4 & 1.73 & 1.26 & 59.2 & 25.8 & 4.1 & 12.7 & 0.36 \\
\hline 16 & 11.3 & 44.7 & 1.79 & 1.22 & 53.8 & 25.9 & 4.8 & 12.3 & 0.41 \\
\hline 17 & 11.5 & 45.2 & 1.74 & 1.25 & 56.7 & 25.8 & 5.3 & 12.4 & 0.36 \\
\hline 18 & 11.6 & 44.9 & 1.72 & 1.28 & 55.3 & 26.1 & 5.1 & 12.9 & 0.32 \\
\hline 19 & 11.7 & 44.6 & 1.70 & 1.12 & 57.2 & 26.0 & 5.9 & 13.2 & 0.33 \\
\hline 20 & 11.9 & 44.5 & 1.69 & 1.21 & 53.4 & 25.7 & 6.1 & 13.2 & 0.32 \\
\hline 21 & 12.3 & 44.6 & 1.73 & 1.28 & 51.7 & 25.7 & 6.0 & 13.1 & 0.37 \\
\hline 22 & 12.5 & 43.6 & 1.72 & 1.23 & 52.4 & 25.4 & 6.4 & 12.1 & 0.37 \\
\hline 23 & 12.7 & 43.5 & 1.75 & 1.23 & 52.1 & 25.4 & 6.8 & 12.5 & 0.30 \\
\hline 24 & 12.9 & 43.7 & 1.77 & 1.22 & 54.1 & 25.8 & 6.3 & 12.8 & 0.31 \\
\hline 25 & 13.1 & 42.6 & 1.79 & 1.25 & 51.9 & 25.3 & 7.1 & 12.3 & 0.33 \\
\hline 26 & 13.4 & 42.7 & 1.77 & 1.15 & 51.8 & 25.3 & 7.3 & 12.3 & 0.31 \\
\hline 27 & 13.6 & 42.4 & 1.78 & 1.24 & 55.6 & 25.6 & 7.1 & 13.2 & 0.35 \\
\hline 28 & 13.7 & 42.1 & 1.76 & 1.26 & 54.8 & 25.4 & 6.9 & 13.2 & 0.37 \\
\hline 29 & 13.9 & 41.8 & 1.76 & 1.18 & 57.3 & 25.7 & 7.2 & 13.1 & 0.32 \\
\hline 30 & 14.0 & 41.5 & 1.78 & 1.26 & 55.6 & 25.4 & 7.5 & 12.8 & 0.30 \\
\hline 31 & 14.1 & 41.1 & 1.78 & 1.24 & 54.8 & 25.3 & 7.6 & 12.9 & 0.31 \\
\hline 32 & 14.4 & 40.4 & 1.75 & 1.22 & 54.6 & 25.5 & 7.2 & 12.9 & 0.32 \\
\hline 33 & 14.5 & 40.2 & 1.76 & 1.23 & 52.4 & 25.6 & 6.9 & 12.5 & 0.33 \\
\hline 34 & 14.7 & 40.1 & 1.78 & 1.11 & 53.4 & 25.7 & 6.8 & 12.3 & 0.31 \\
\hline 35 & 14.8 & 40.2 & 1.78 & 1.13 & 54.1 & 25.7 & 6.2 & 12.3 & 0.30 \\
\hline 36 & 15.0 & 40.4 & 1.77 & 1.22 & 53.8 & 25.5 & 6.8 & 12.7 & 0.31 \\
\hline
\end{tabular}

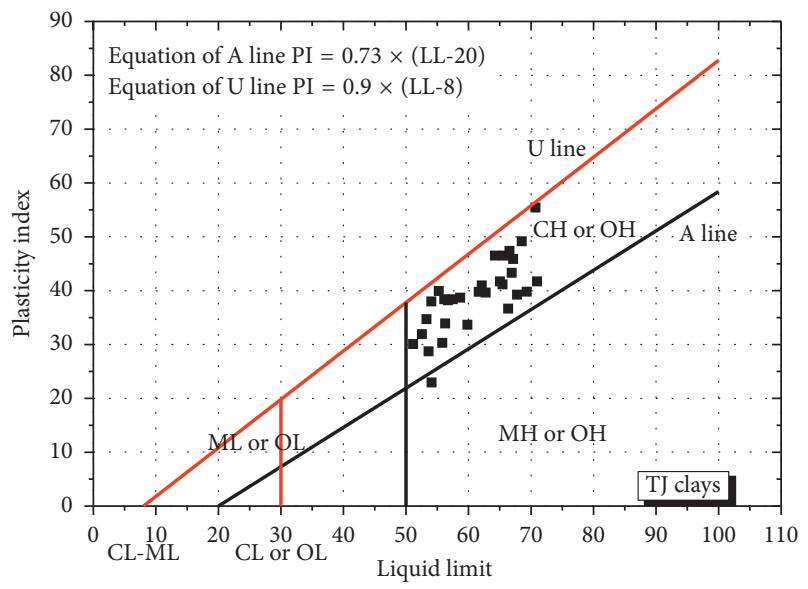

FIgURe 2: Plasticity chart of the tested Tianjin clays.

cylinder was $457 \mathrm{~mm}$, the diameter was $63.5 \mathrm{~mm}$, and the marked volume was $1,000 \mathrm{~mL}$. Sodium hexametaphosphate was generally used as the dispersing agent. The volume of the dispersed soil suspension was increased to $1,000 \mathrm{~mL}$ by adding distilled water. From the start of sedimentation, a hydrometer was placed in the soil suspension at a certain time $t$ to measure the density of the suspension in the vicinity of its bulb at a certain depth $L$. Then, the percentage of particles surpassing a certain size was calculated according to Stokes's law. The particle-size distribution curve of the soil is shown in Figure 3, which demonstrates that the particle sizes were distributed over a wide range and that the soils were well graded. The clay content $(<5 \mu \mathrm{m})$ was approximately $53 \%$.

2.2. Test Apparatus and Procedures. A cyclic triaxial testing apparatus (British Geotechnical Digital Systems (GDS) Instruments, Ltd., Unit 32 Murrell Green Business Park, London, United Kingdom) was used to test the deformation behaviours of the soil samples under repeated loading. The cyclic triaxial testing apparatus, which mainly consisted of a triaxial pressure chamber, a cell pressure controller, a back 


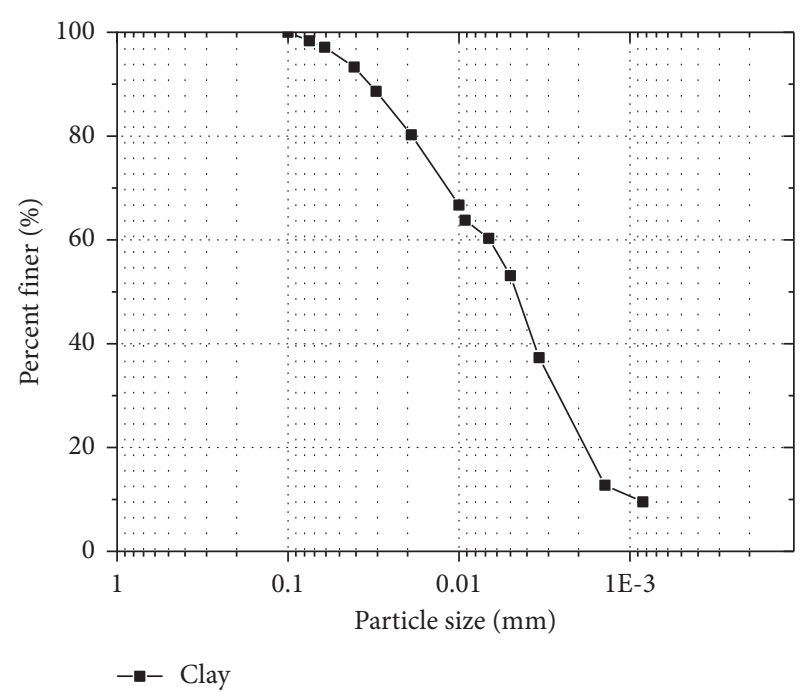

Figure 3: Particle-size distribution curve of a typical Tianjin clay.

pressure controller, an axial loading driver, a water supplier, two data collectors, and a computer, met the demands of saturation and consolidation testing, standard and advanced triaxial testing, stress path testing, permeability testing, and bender element testing, as shown in Figure 4.

The advanced triaxial testing module mainly includes a stress loading control module and a strain loading control module. The stress loading control module can be divided into static and dynamic loading programs. Different loading paths and anisotropic consolidation states can be set in the static loading process, which is different from the standard triaxial testing. With respect to the dynamic loading, the dynamic loading frequency range is from $0.1 \mathrm{~Hz}$ to $5 \mathrm{~Hz}$. Different loading sine wave types and amplitudes can be selected, and the wave type functions can be set through vibration monitoring data in the dynamic loading program. Similarly, the strain loading control module includes static loading and dynamic loading. The functions and settings are consistent with the stress loading module.

The specimen was carefully prepared to prevent any disturbance to the soil. Before the test, the specimen preparation and installation processes were as follows. The sample was cut into a cylindrical specimen with a diameter of $39.1 \mathrm{~mm}$ and a height of $80 \mathrm{~mm}$ and placed into the apparatus, as shown in Figures 5(a) and 5(b). The specimen was then placed into a saturated container for extraction and saturation, as shown in Figure 5(c). When the vacuum pressure approached $100 \mathrm{kPa}$, the vacuum pump continued pumping for 2 additional hours. Then, the inlet valve was opened, and distilled water was slowly added to the container. The specimen was placed in the distilled water for more than $10 \mathrm{~h}$. The specimen was then removed from the apparatus, and a rubber membrane, hollow bearing membrane tube, and Hill sphere were used to cover the specimen, as shown in Figures 5(d) and 5(e). The specimen was then carefully installed in the triaxial pressure chamber before commencing the test. To simulate the initial stress state of natural soil, the sample was consolidated using the advanced triaxial testing module under anisotropic consolidation,

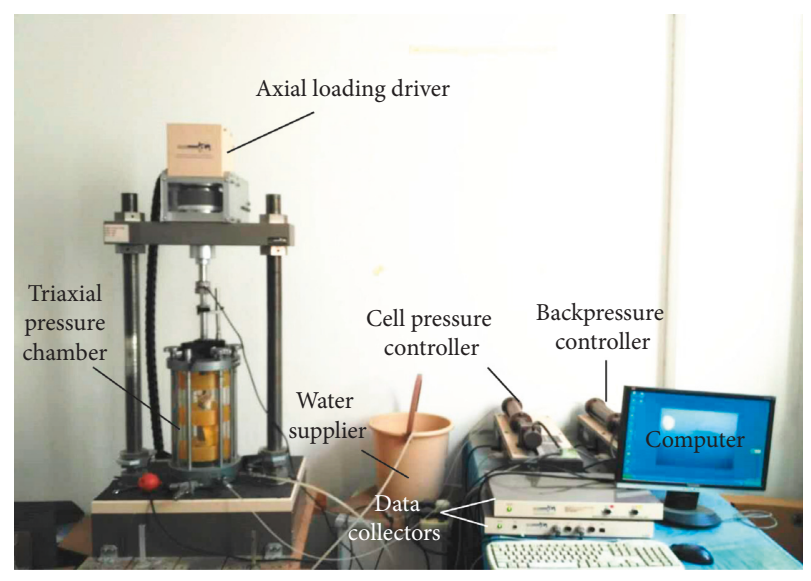

FIgURE 4: Cyclic triaxial testing apparatus.

$K_{\mathrm{c}}=2$, for more than $24 \mathrm{~h}$, until the axial strain rate was less than $0.05 \%$ per hour.

To simulate the seepage flow in the specimen during the cyclic triaxial tests, water pressure was applied at the bottom of the specimen, and the water can be drained from the top of the specimen to form a head difference between the bottom and top of the specimen (Figure 6). Vaseline was spread on the periphery of the specimen to prevent water from flowing through the gap between the specimen and the rubber membrane. The cyclic triaxial tests were conducted with the advanced triaxial test software module using sinusoidal waveforms and preset parameters (e.g., frequency and amplitude) until the chosen number of cycles was completed, as shown in Figure 5(f). All the tests were performed at room temperature $\left(20 \pm 2^{\circ} \mathrm{C}\right)$.

2.3. Cases Tested. The deformation behaviours of Tianjin clays under coupled dynamic stress and seepage loads were systematically investigated. A confining stress of $100 \mathrm{kPa}$ was applied; applied water pressures of $20 \mathrm{kPa}, 50 \mathrm{kPa}, 100 \mathrm{kPa}$, and $150 \mathrm{kPa}$ were selected; CSR values of $0.1,0.2$, and 0.3 were used; sinusoidal waves were used; a vibration frequency of $1 \mathrm{~Hz}$ was selected; and cycle numbers of 500, 2,000, and 5,000 were selected to study the deformation behaviours of Tianjin clays under coupled dynamic stress and seepage flow. Figure 7 presents the loading pattern in the cyclic triaxial tests. In the initial stage of consolidation, confining stress of $100 \mathrm{kPa}$ and axial stress of $200 \mathrm{kPa}$ were selected. The CSR value was defined as follows:

$$
\operatorname{CSR}=\frac{\sigma_{\mathrm{d}}}{2 \sigma}
$$

where $\sigma_{\mathrm{d}}$ is the dynamic stress and $\sigma$ is the confining pressure. The cases tested are shown in Table 2.

\section{Test Results and Discussion}

Thirty-six cyclic triaxial tests were conducted, as shown in Table 2. Some interesting phenomena were observed regarding the cyclic deformation characteristics of Tianjin clays under coupled dynamic stress and seepage fields, as described in detail below. 


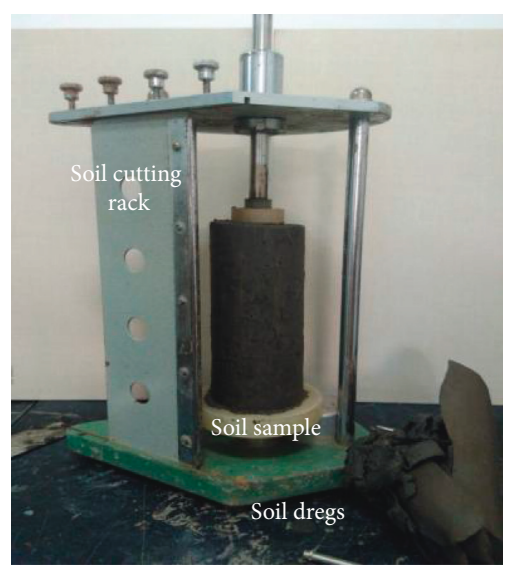

(a)

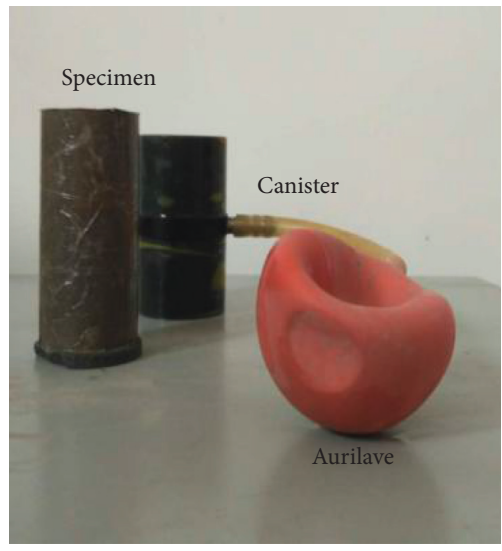

(d)

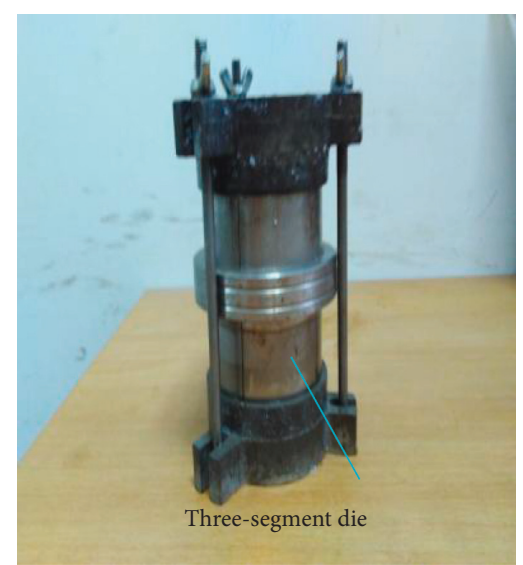

(b)

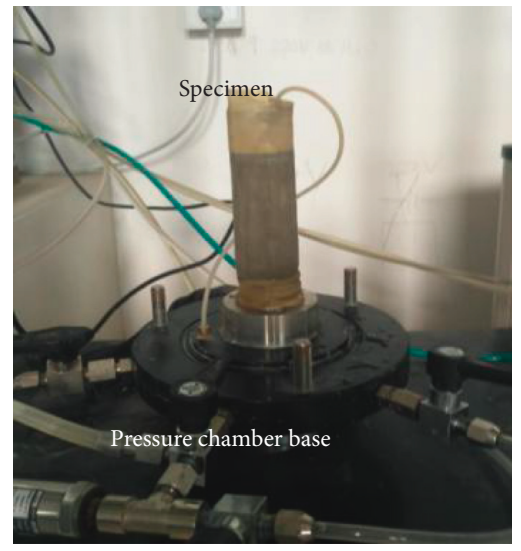

(e)

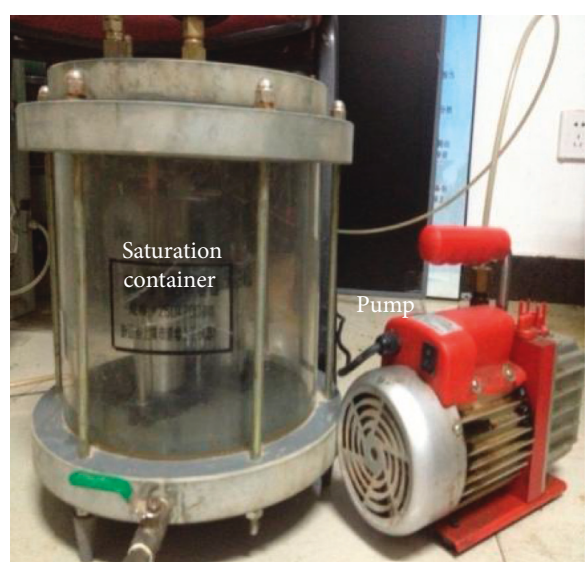

(c)

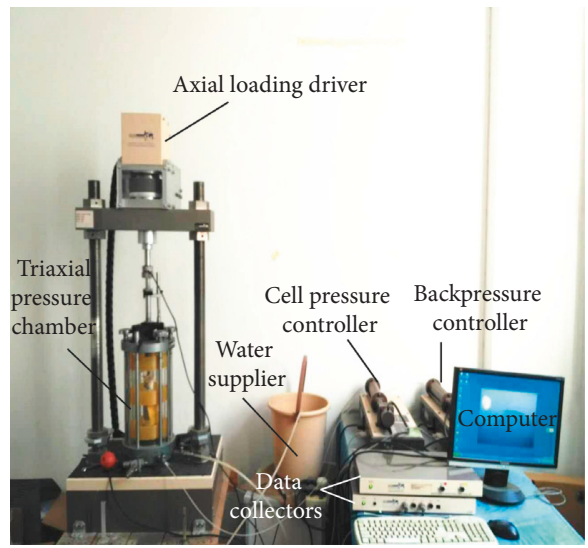

(f)

FIGURE 5: Specimen preparation process for a cyclic triaxial test: (a) cutting the soil; (b) placing the specimen in the three-segment die; (c) saturating in the saturation container; (d) covering the specimen; (e) installing the specimen; (f) conducting the cyclic triaxial test.

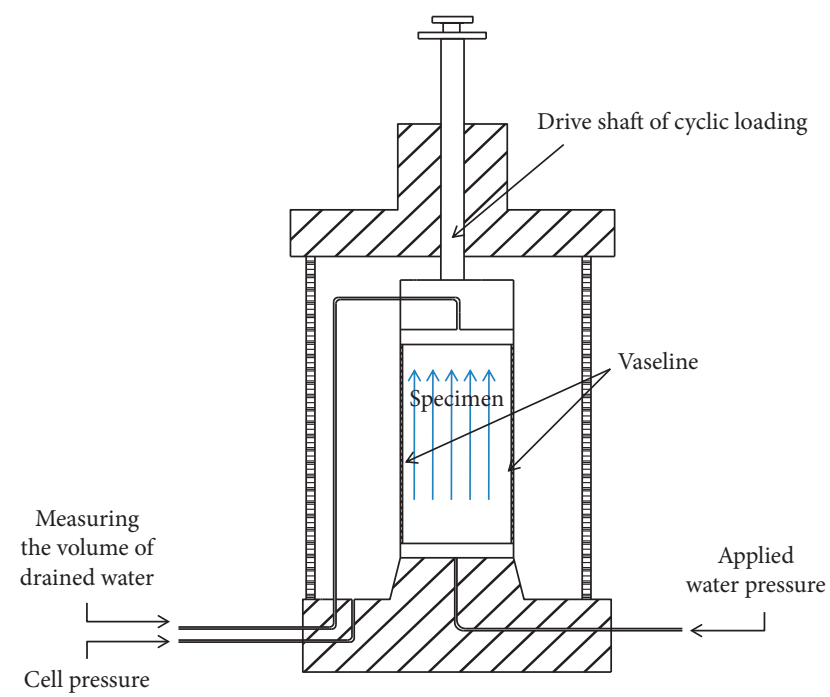

FIgURE 6: Principle of forming seepage flow in the specimen.

3.1. Hydraulic Conductivity under Coupled Dynamic Stress and Seepage Fields. The head difference between the bottom and top of the specimen was formed in the cyclic triaxial tests

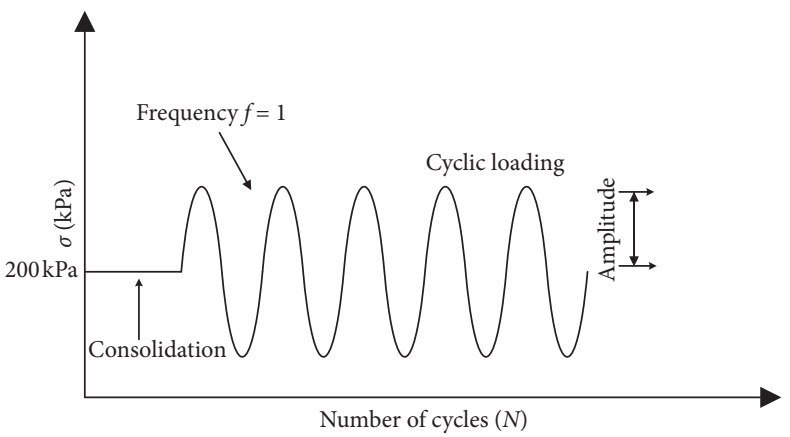

Figure 7: Loading pattern in the cyclic triaxial tests.

to simulate the seepage field. The applied water pressures at the bottom of the specimen were $20 \mathrm{kPa}, 50 \mathrm{kPa}, 100 \mathrm{kPa}$, and $150 \mathrm{kPa}$. The evolution of the hydraulic conductivity was investigated in this study. The hydraulic conductivity $(k)$ was determined according to the collected water volume and the hydraulic gradient in the specimen, which is the same as the determination method in the constant head test. The values of $k$ were calculated according to the following equations: 
TABle 2: Cases tested.

\begin{tabular}{|c|c|c|c|c|c|c|}
\hline Test number & $\begin{array}{l}\text { Depth } \\
(\mathrm{m})\end{array}$ & $\begin{array}{l}\text { Applied water } \\
\text { pressure }(\mathrm{kPa})\end{array}$ & Number of cycles, $N$ & Cyclic stress ratio, CSR & Cell pressure $(\mathrm{kPa})$ & Vibration frequency $(\mathrm{Hz})$ \\
\hline A 1 & 8.1 & 20 & 500 & 0.1 & \multirow{4}{*}{100} & \multirow{4}{*}{1} \\
\hline A 2 & 8.3 & 50 & 500 & 0.1 & & \\
\hline A 3 & 8.5 & 100 & 500 & 0.1 & & \\
\hline A 4 & 8.6 & 150 & 500 & 0.1 & & \\
\hline A 5 & 8.9 & 20 & 2,000 & 0.1 & \multirow{4}{*}{100} & \multirow{4}{*}{1} \\
\hline A 6 & 9.1 & 50 & 2,000 & 0.1 & & \\
\hline A 7 & 9.4 & 100 & 2,000 & 0.1 & & \\
\hline A 8 & 9.7 & 150 & 2,000 & 0.1 & & \\
\hline A 9 & 9.9 & 20 & 5,000 & 0.1 & \multirow{4}{*}{100} & \multirow{4}{*}{1} \\
\hline A 10 & 10.3 & 50 & 5,000 & 0.1 & & \\
\hline A 11 & 10.5 & 100 & 5,000 & 0.1 & & \\
\hline A 12 & 10.6 & 150 & 5,000 & 0.1 & & \\
\hline A 13 & 10.8 & 20 & 500 & 0.2 & \multirow{4}{*}{100} & \multirow{4}{*}{1} \\
\hline A 14 & 10.9 & 50 & 500 & 0.2 & & \\
\hline A 15 & 11.1 & 100 & 500 & 0.2 & & \\
\hline A 16 & 11.3 & 150 & 2,000 & 0.2 & & \\
\hline A 17 & 11.5 & 20 & 2,000 & 0.2 & \multirow{4}{*}{100} & \multirow{4}{*}{1} \\
\hline A 18 & 11.6 & 50 & 2,000 & 0.2 & & \\
\hline A 19 & 11.7 & 100 & 2,000 & 0.2 & & \\
\hline A 20 & 11.9 & 150 & 2,000 & 0.2 & & \\
\hline A 21 & 12.3 & 20 & 5,000 & 0.2 & \multirow{4}{*}{100} & \multirow{4}{*}{1} \\
\hline A 22 & 12.5 & 50 & 5,000 & 0.2 & & \\
\hline A 23 & 12.7 & 100 & 5,000 & 0.2 & & \\
\hline A 24 & 12.9 & 150 & 5,000 & 0.2 & & \\
\hline A 25 & 13.1 & 20 & 500 & 0.3 & \multirow{4}{*}{100} & \multirow{4}{*}{1} \\
\hline A 26 & 13.4 & 50 & 500 & 0.3 & & \\
\hline A 27 & 13.6 & 100 & 500 & 0.3 & & \\
\hline A 28 & 13.7 & 150 & 500 & 0.3 & & \\
\hline A 29 & 13.9 & 20 & 2,000 & 0.3 & \multirow{5}{*}{100} & \multirow{4}{*}{1} \\
\hline A 30 & 14.0 & 50 & 2,000 & 0.3 & & \\
\hline A 31 & 14.1 & 100 & 2,000 & 0.3 & & \\
\hline A 32 & 14.4 & 150 & 2,000 & 0.3 & & \\
\hline A 33 & 14.5 & 20 & 5,000 & 0.3 & & \multirow{4}{*}{1} \\
\hline A 34 & 14.7 & 50 & 5,000 & 0.3 & \multirow{3}{*}{100} & \\
\hline A 35 & 14.8 & 100 & 5,000 & 0.3 & & \\
\hline A 36 & 15.0 & 150 & 5,000 & 0.3 & & \\
\hline
\end{tabular}

$$
\begin{aligned}
& k=\frac{v}{i}=\frac{Q}{i A t}, \\
& i=\frac{\Delta h}{L},
\end{aligned}
$$

where $A$ is the cross-sectional area of the specimen; $t$ is the time; $i$ is the hydraulic gradient; $Q$ is the drained water volume due to seepage flow, which equals the total collected water volume minus the drained water volume due to the consolidation deformation of the specimen; $\Delta h$ is the head difference; and $L$ is the length of flow-over, which is equal to the initial sample height minus the deformation height. The collected water volume was measured every 5 minutes, and the average value of $k$ was calculated every 5 minutes.

Four water pressure values of $20 \mathrm{kPa}, 50 \mathrm{kPa}, 100 \mathrm{kPa}$, and $150 \mathrm{kPa}$ applied at the bottom of the specimen were chosen to calculate $i$ according to equation (3). To investigate the relationships between discharge velocity and hydraulic gradient under different CSR and $N$ values, the deformation, hydraulic gradient, and discharge velocity data are provided in Table 3. The hydraulic conductivity decreases with $N$. With an applied water pressure of $150 \mathrm{kPa}$ and CSR of 0.3 , the hydraulic conductivities are $6.8 \times 10^{-8} \mathrm{~cm} / \mathrm{s}, 5.2 \times$ $10^{-8} \mathrm{~cm} / \mathrm{s}$, and $4.6 \times 10^{-8} \mathrm{~cm} / \mathrm{s}$, respectively, for $N$ values of $500,2,000$, and 5,000. The hydraulic conductivity also decreases with the seepage pressure. With a CSR of 0.3 and an $N$ of 5,000 , the hydraulic conductivities are $7.4 \times 10^{-8} \mathrm{~cm} / \mathrm{s}$, $6.5 \times 10^{-8} \mathrm{~cm} / \mathrm{s}, \quad 6.3 \times 10^{-8} \mathrm{~cm} / \mathrm{s}$, and $4.6 \times 10^{-8} \mathrm{~cm} / \mathrm{s}$, respectively, for the water pressures of $20 \mathrm{kPa}, 50 \mathrm{kPa}, 100 \mathrm{kPa}$, and $150 \mathrm{kPa}$ applied at the bottom of the specimen.

To evaluate the effect of cyclic loading on the hydraulic conductivity, Figure 8 presents the relationships between the discharge velocity and hydraulic gradient under different CSR values. Figure 8 shows that the hydraulic conductivity (the slope of the secant line of the curve) decreases with increasing CSR. With an applied water pressure of $150 \mathrm{kPa}$ and $N$ of 5,000, the hydraulic conductivities are $6.1 \times 10^{-8} \mathrm{~cm} / \mathrm{s}, 4.9 \times 10^{-8} \mathrm{~cm} / \mathrm{s}$, and $4.6 \times 10^{-8} \mathrm{~cm} / \mathrm{s}$ for CSR of $0.1,0.2$, and 0.3 , respectively. Therefore, the higher CSR and seepage pressure induces a greater strain, resulting in a lower hydraulic conductivity. 
TABLE 3: Calculated values of the hydraulic gradient and discharge velocity.

\begin{tabular}{|c|c|c|c|c|c|}
\hline Applied water pressure $(\mathrm{kPa})$ & CSR & $N$ & Deformation $(\mathrm{mm})$ & Hydraulic gradient & Discharge velocity $\left(\mathrm{m} / \mathrm{s} \times 10^{-7}\right)$ \\
\hline \multirow{9}{*}{ 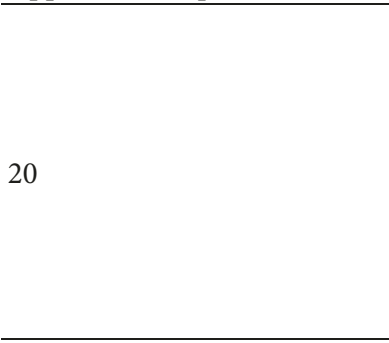 } & \multirow{3}{*}{0.1} & 500 & 0.45 & 25.14 & 2.5 \\
\hline & & 2,000 & 0.65 & 25.20 & 2.1 \\
\hline & & 5,000 & 0.94 & 25.30 & 1.55 \\
\hline & \multirow{3}{*}{0.2} & 500 & 0.64 & 25.20 & 2.31 \\
\hline & & 2,000 & 0.88 & 25.28 & 1.98 \\
\hline & & 5,000 & 1.01 & 25.32 & 1.42 \\
\hline & \multirow{3}{*}{0.3} & 500 & 0.82 & 25.26 & 2.21 \\
\hline & & 2,000 & 1.21 & 25.38 & 1.89 \\
\hline & & 5,000 & 1.46 & 25.46 & 1.4 \\
\hline \multirow{9}{*}{50} & \multirow{3}{*}{0.1} & 500 & 0.49 & 62.89 & 5.3 \\
\hline & & 2,000 & 0.77 & 63.11 & 5.01 \\
\hline & & 5,000 & 0.98 & 63.20 & 3.8 \\
\hline & \multirow{3}{*}{0.2} & 500 & 0.9 & 63.21 & 5.21 \\
\hline & & 2,000 & 1.19 & 63.44 & 4.9 \\
\hline & & 5,000 & 1.27 & 63.51 & 3.34 \\
\hline & \multirow{3}{*}{0.3} & 500 & 1.1 & 63.37 & 5.12 \\
\hline & & 2,000 & 1.4 & 63.61 & 4.75 \\
\hline & & 5,000 & 1.47 & 63.67 & 4.21 \\
\hline \multirow{9}{*}{100} & \multirow{3}{*}{0.1} & 500 & 0.83 & 126.31 & 10.34 \\
\hline & & 2,000 & 1.1 & 126.74 & 9.76 \\
\hline & & 5,000 & 1.36 & 132.21 & 10 \\
\hline & \multirow{3}{*}{0.2} & 500 & 1.28 & 127.03 & 9.98 \\
\hline & & 2,000 & 1.92 & 128.07 & 9.54 \\
\hline & & 5,000 & 2.24 & 128.60 & 8.9 \\
\hline & \multirow{3}{*}{0.3} & 500 & 1.19 & 126.89 & 9.78 \\
\hline & & 2,000 & 1.96 & 128.14 & 8.9 \\
\hline & & 5,000 & 2.33 & 128.75 & 8.2 \\
\hline \multirow{9}{*}{150} & \multirow{3}{*}{0.1} & 500 & 1.35 & 193.17 & 15.11 \\
\hline & & 2,000 & 1.95 & 197.24 & 14.23 \\
\hline & & 5,000 & 2.51 & 201.10 & 12.34 \\
\hline & \multirow{3}{*}{0.2} & 500 & 2.37 & 194.07 & 14.31 \\
\hline & & 2,000 & 2.86 & 198.33 & 13.66 \\
\hline & & 5,000 & 3.17 & 201.95 & 9.98 \\
\hline & \multirow{3}{*}{0.3} & 500 & 2.72 & 195.06 & 13.24 \\
\hline & & 2,000 & 3.44 & 199.87 & 10.32 \\
\hline & & 5,000 & 3.82 & 203.69 & 9.45 \\
\hline
\end{tabular}

3.2. Axial Deformation under Coupled Dynamic Stress and Seepage Fields. In general, cyclic deformation is closely related to $N$ under undrained conditions in cyclic triaxial tests. The greater the number of cycles is, the larger the deformation that is induced is [31]. However, few researchers have experimentally studied the relationship between deformation and $N$ under coupled dynamic stress and seepage fields. To investigate the cyclic deformation under coupled dynamic stress and seepage fields, the relationships between the seepage pressure and axial deformation and the correlations between $N$ and axial deformation under different seepage pressures and CSRs were investigated.

Figure 9 presents the axial deformation of Tianjin clays under different $N$ values. Clearly, the development of deformation exhibits an increasing trend with increasing $N$, which is similar to that under undrained conditions. With a CSR of 0.3 and applied water pressure of $150 \mathrm{kPa}$, the axial deformations are $2.72 \mathrm{~mm}, 3.44 \mathrm{~mm}$, and $3.82 \mathrm{~mm}$ for $N$ values of 500, 2,000, and 5,000, respectively.

The axial deformation increases with seepage pressure. With an $N$ of 5,000 and a CSR of 0.3 , the axial deformations are $1.46 \mathrm{~mm}, 1.47 \mathrm{~mm}, 2.33 \mathrm{~mm}$, and $3.82 \mathrm{~mm}$ for the water pressures of $20 \mathrm{kPa}, 50 \mathrm{kPa}, 100 \mathrm{kPa}$, and $150 \mathrm{kPa}$ applied at the bottom of the specimen, respectively. The axial deformation also increases with increasing CSR. With an $N$ of 500 and an applied water pressure of $150 \mathrm{kPa}$, the axial deformations are $1.35 \mathrm{~mm}, 2.37 \mathrm{~mm}$, and $2.72 \mathrm{~mm}$ for CSRs of $0.1,0.2$, and 0.3 , respectively. With an $N$ of 2,000 and an applied water pressure of $150 \mathrm{kPa}$, the axial deformations are $1.95 \mathrm{~mm}, 2.86 \mathrm{~mm}$, and $3.44 \mathrm{~mm}$ for CSRs of $0.1,0.2$, and 0.3 , respectively. With an $N$ of 5,000 and an applied water pressure of $150 \mathrm{kPa}$, the axial deformations reach $2.5 \mathrm{~mm}$, $3.17 \mathrm{~mm}$, and $3.82 \mathrm{~mm}$ for CSRs of $0.1,0.2$, and 0.3 , respectively. Therefore, the axial deformation of Tianjin clays is attributed to the coupled action of the applied seepage pressure and cyclic loading. With an applied water pressure of $150 \mathrm{kPa}$ and a CSR of 0.3 , a large displacement of $3.82 \mathrm{~mm}$ is induced, and the cumulative plastic strain reaches $4.78 \%$.

For increasing CSR values, the initial deformation increases rapidly, and both the deformation development rate and deformation of the clays are large. Plastic deformation of the soil occurs as $N$ is increased. When the accumulation rate 


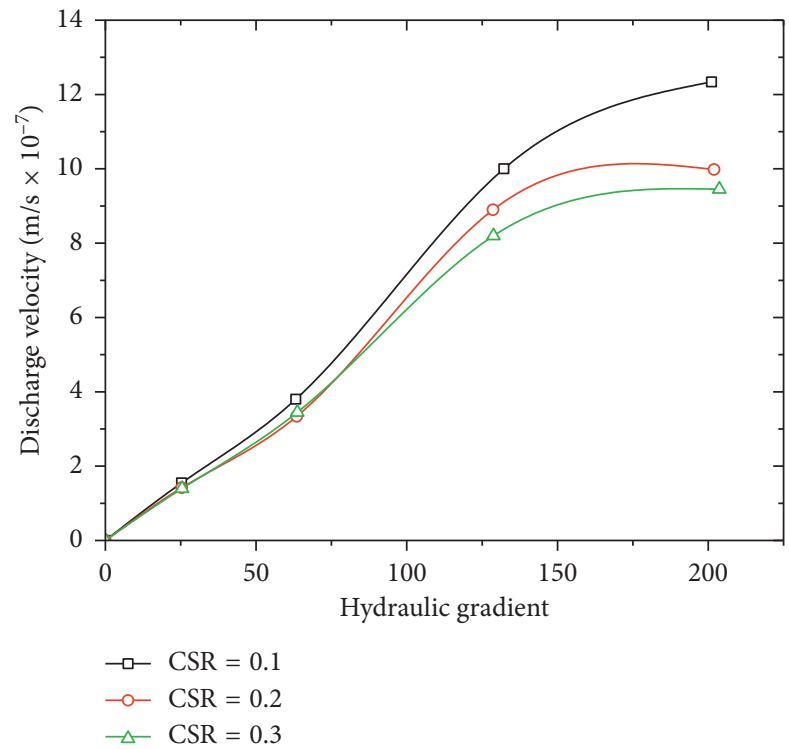

Figure 8: Relationships between the discharge velocity and hydraulic gradient under different CSR values with an $N$ value of 5,000.

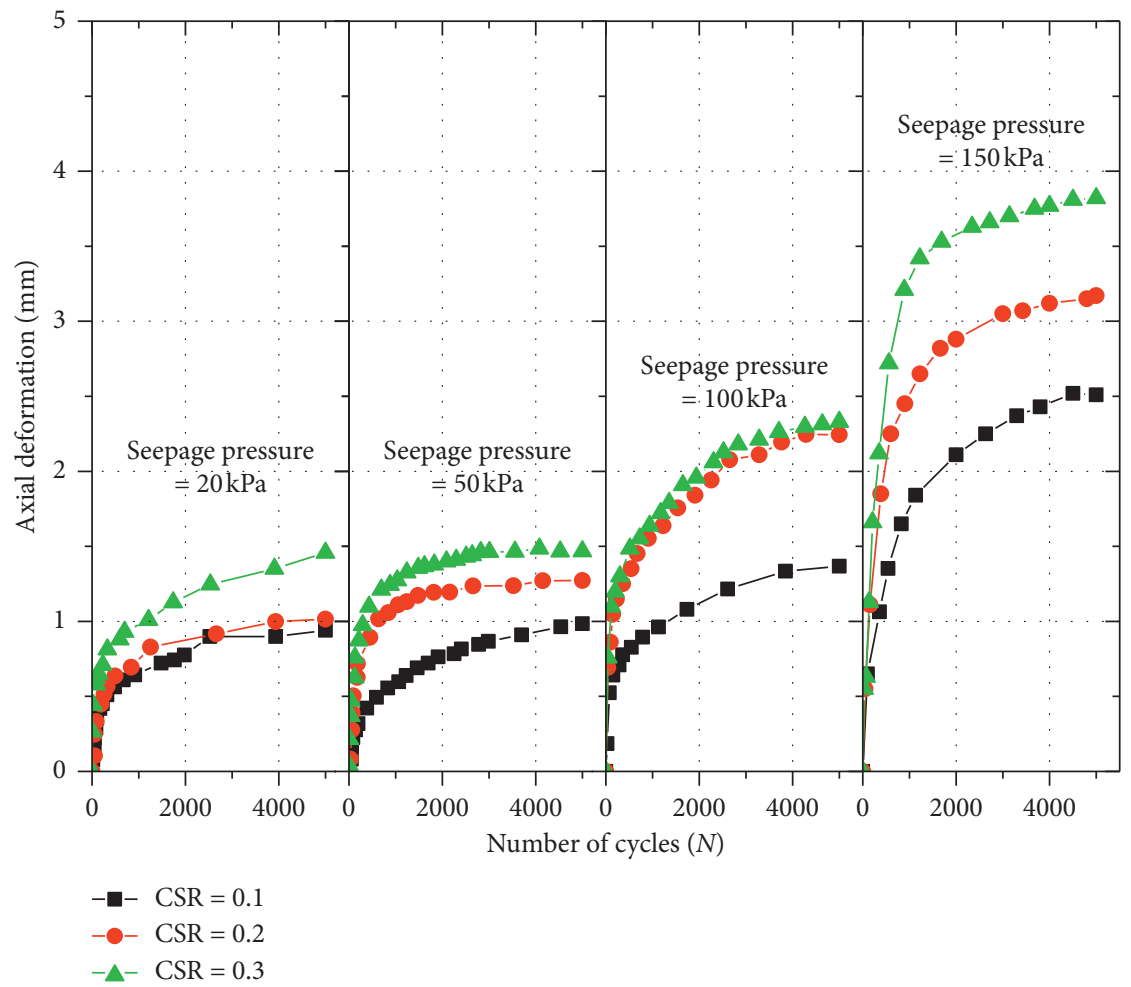

Figure 9: Relationships between axial deformation and $N$ under different CSR values and seepage pressures.

slows, the deformation continues to increase until the deformation development stabilizes. Under higher cyclic stress, the development rate of deformation and the deformation increment increase. This result is mainly because the soil pores are more likely to be filled with soil particles under the higher cyclic stress condition, leading to soil compaction, and the soil undergoes irreversible plastic deformation.
3.3. Hysteresis Curves and Dynamic Modulus. Three different CSR values, $0.1,0.2$, and 0.3 , were used to investigate the effect of CSR on the hysteresis curves (Figure 10). Hysteresis curves can be used to evaluate the cumulative energy consumption and dynamic deformation characteristics. The hysteresis curve represents the relationship between the dynamic stress and the dynamic strain in a given stress cycle. Since the cumulative plastic strain increases with increasing 


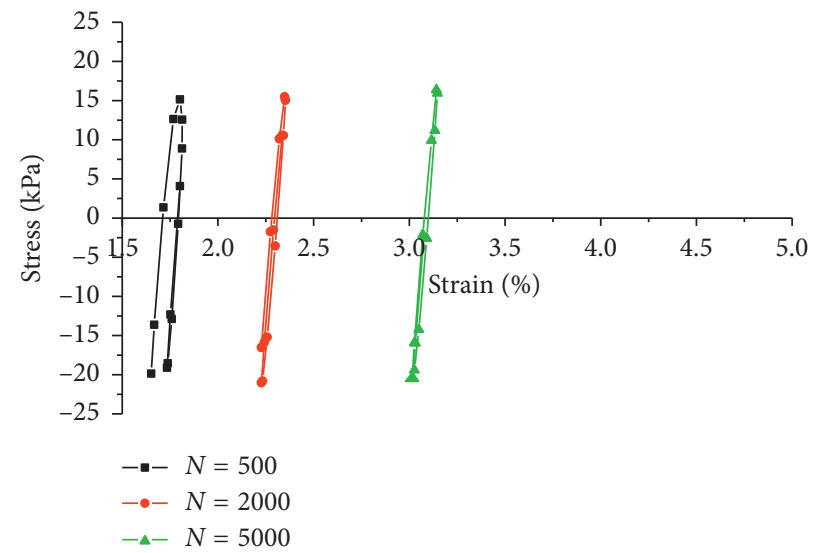

(a)

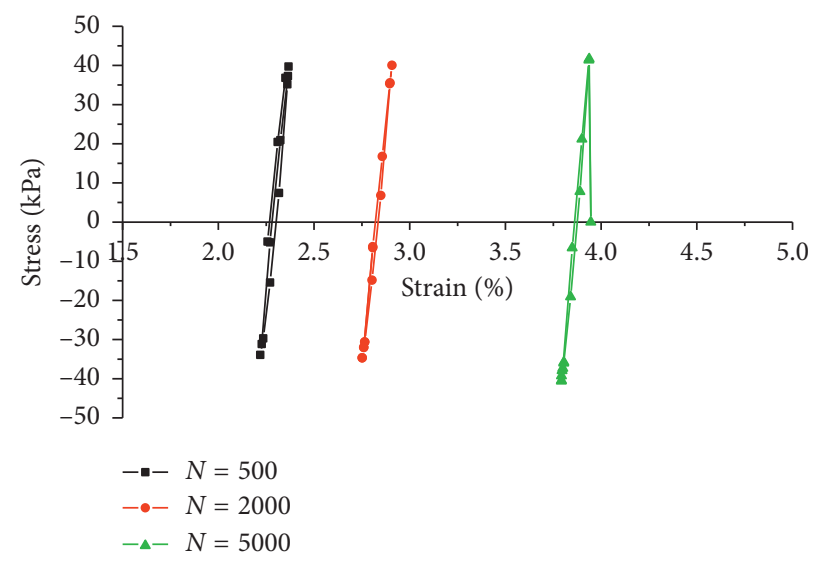

(b)

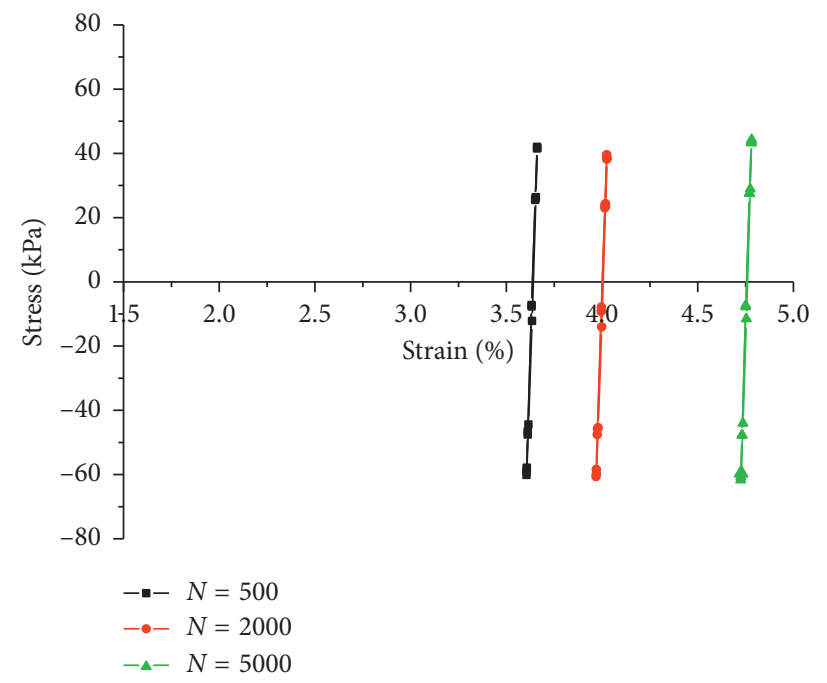

(c)

Figure 10: Hysteresis curves of Tianjin clays: (a) $\operatorname{CSR}=0.1$; (b) $\operatorname{CSR}=0.2$; (c) $\operatorname{CSR}=0.3$.

seepage pressure, the water pressure of $150 \mathrm{kPa}$ applied at the bottom of the specimen was selected to investigate the hysteresis curves of Tianjin clays under coupled dynamic stress and seepage flow.

Figure 10 demonstrates that, with increasing $N$, the centre of the hysteresis curve shifts gradually to the right along the $x$ axis, and the cumulative plastic deformation of the soil increases under cyclic loading, indicating that the cumulative plastic strain increases with $N$. The CSR also plays an important role in the cumulative plastic deformation: the greater the dynamic stress ratio is, the greater the cumulative plastic deformation is. When the CSR value is 0.3 , the hysteresis loop is the thinnest and shows a greater degree of aggregation than those for CSR values of 0.1 and 0.2. Furthermore, the hysteresis loop becomes steeper with increasing $N$ and CSR, demonstrating that $N$ and CSR improve the stiffness of soils. This phenomenon is different from the dynamic characteristics of the soft soil observed in the undrained condition. With a CSR of 0.3 and an $N$ of 5,000, the cumulative plastic strain reaches $4.78 \%$; the reason for this phenomenon is that a high seepage pressure and CSR can accelerate the consolidation of clay under drained conditions.
Figure 10 also shows that all the hysteresis curves are open, and the smaller the CSR, the greater the hysteresis of the soft soil. The hysteresis curve flattens when the CSR reaches 0.3 , which demonstrates that there is no plastic deformation of the soil, and the elastic deformation only exists during loading and unloading. The deformation remains stable with increasing $N$.

The cyclic deformation properties of soft soil depend on the dynamic modulus, which is significant in evaluating the cyclic deformation of soft marine soil [32]. The dynamic modulus $E_{\mathrm{d}}$ can be obtained according to the stress-strain relations of soil subjected to cyclic loading. Therefore, $E_{\mathrm{d}}$ can be calculated by the following equation:

$$
E_{\mathrm{d}}=\frac{\sigma_{\mathrm{d}}}{\varepsilon_{\mathrm{d}}}
$$

where $\sigma_{\mathrm{d}}$ is the dynamic deviator stress and $\varepsilon_{\mathrm{d}}$ is the dynamic strain, which can be defined as follows:

$$
\varepsilon_{\mathrm{d}}=\frac{1}{2}\left(\varepsilon_{\max }-\varepsilon_{\min }\right) .
$$


Figure 11(a) shows that the dynamic modulus increases with $N$ for a given CSR under an applied water pressure of $150 \mathrm{kPa}$. When $N$ is less than 2,000, the initial dynamic modulus presents an increasing trend, and the rate of increase accelerates. When $N$ is greater than 2,000, the curves of the dynamic modulus remain stable. The values of the dynamic modulus are 11.11 MPa, 14.92 MPa, and 19.04 MPa with CSR values of $0.1,0.2$, and 0.3 , respectively. The dynamic modulus under a higher CSR is greater than that under a lower CSR. This phenomenon is different from that observed for soil subjected to cyclic loading under undrained conditions because soil particles are compacted under drained conditions, improving the stiffness of the soil.

Figure 11(b) shows that the dynamic modulus increases with $N$ for a given seepage pressure under a CSR value of 0.3 . When $N$ is less than 20 , the dynamic modulus increases with the seepage pressure. For example, with a CSR value of 0.3 and an $N$ of 20 , the values of the dynamic modulus are $3.1 \mathrm{MPa}$, 2.6 MPa, 2.2 MPa, and 1.88 MPa for applied water pressures of $20 \mathrm{kPa}, 50 \mathrm{kPa}, 100 \mathrm{kPa}$, and $150 \mathrm{kPa}$, respectively. This result implies that a larger deformation of the soil sample occurs in the early stage of loading. However, when $N$ is greater than 100 , the dynamic modulus increases with increasing seepage pressure. With a CSR of 0.3 and an $N$ of 100 , the values of the dynamic modulus are $4.4 \mathrm{MPa}, 5.5 \mathrm{MPa}, 7.4 \mathrm{MPa}$, and 10.2 MPa for the applied water pressures of $20 \mathrm{kPa}, 50 \mathrm{kPa}$, $100 \mathrm{kPa}$, and $150 \mathrm{kPa}$, respectively. When $N$ is greater than 2,000 , the dynamic modulus increases slowly. With a CSR of 0.3 and an $N$ of 2,000, the values of the dynamic modulus are 8.9 MPa, 9.9 MPa, 14.6 MPa, and 19.04 MPa for the applied water pressures of $20 \mathrm{kPa}, 50 \mathrm{kPa}, 100 \mathrm{kPa}$, and $150 \mathrm{kPa}$, respectively.

To describe and evaluate the dynamic modulus under the coupled dynamic stress and seepage fields, the empirical equations of the dynamic modulus under the different CSR values and applied water pressures were established by regression analysis. The equation can help engineers evaluate and predict the large deformation of Tianjin clays subjected to cyclic loading and seepage flow:

$$
E_{\mathrm{d}}=A \ln (N)+B,
$$

where $N$ is the number of cycles and $A$ and $B$ are the test parameters, which are related to the CSR and seepage pressure, as shown in Table 4.

The established empirical equations with different CSR values and seepage pressures may help engineers make decisions as soon as possible in the Tianjin Binhai New Area when geological survey reports and other detailed materials are not available.

Figure 12 shows the failure mode of samples subjected to the coupled dynamic loading and seepage forces. Under different CSRs and different water pressures, the failure mode of soft soil is identical, and the final failure is a swelling failure. The swelling failure of specimens is a gradual process that expands from a local phenomenon to encompassing the entire specimen. The swelling effect of specimens can be described by their diameter. When the CSR is small, swelling of the specimen is not obvious. The diameter of the sample is $40 \mathrm{~mm}$ to $41 \mathrm{~mm}$. By contrast, when the CSR is 0.3 , the maximum diameter of the sample is $49 \mathrm{~mm}$. Similarly, when water pressure is low, the swelling effect is not obvious. When the water pressure is $100 \mathrm{kPa}$, swelling occurs in the middle of the sample, and the maximum diameter is $45 \mathrm{~mm}$. However, swelling is most obvious under a water pressure of $150 \mathrm{kPa}$, which occurs in the middle and upper part of the sample. These findings indicate that, under the combined action of dynamic load and seepage force, the position of soft soil particles changes, resulting in an increase in intergranular pores and volume expansion [33]. Therefore, the failure mode of soil under coupled dynamic-seepage loads should be considered in engineering design.

\section{Conclusions}

The cyclic deformation characteristics of Tianjin clays under coupled cyclic stress and seepage fields have been investigated using cyclic triaxial testing. A series of cyclic triaxial tests have been conducted to systematically investigate the effect of seepage pressure, cyclic stress ratio (CSR), and a number of cycles $(N)$ on the cyclic deformation behaviours of Tianjin clays. The following conclusions can be drawn.

(1) Hydraulic conductivity under coupled dynamic stress and seepage fields:

The hydraulic conductivity of soil subjected to cyclic loading with a CSR of 0.3 is lower than that of soil subjected to cyclic loading with CSRs of 0.2 and 0.1 . In addition, the hydraulic conductivity decreases with increasing $N$ and CSR, ranging from $4.6 \times 10^{-8} \mathrm{~cm} / \mathrm{s}$ to $7.4 \times 10^{-8} \mathrm{~cm} / \mathrm{s}$ during the loading process.

With a CSR of 0.3 , the hydraulic conductivities are $7.4 \times 10^{-8} \mathrm{~cm} / \mathrm{s}, 6.5 \times 10^{-8} \mathrm{~cm} / \mathrm{s}, 6.3 \times 10^{-8} \mathrm{~cm} / \mathrm{s}$, and $4.6 \times 10^{-8} \mathrm{~cm} / \mathrm{s}$ for applied water pressures of $20 \mathrm{kPa}$, $50 \mathrm{kPa}, 100 \mathrm{kPa}$, and $150 \mathrm{kPa}$, respectively. With an applied water pressure of $150 \mathrm{kPa}$ and $N$ of 5,000 , the hydraulic conductivities are $6.1 \times 10^{-8} \mathrm{~cm} / \mathrm{s}$, $4.9 \times 10^{-8} \mathrm{~cm} / \mathrm{s}$, and $4.6 \times 10^{-8} \mathrm{~cm} / \mathrm{s}$ for CSRs of 0.1 , 0.2 , and 0.3 , respectively. With an applied water pressure of $150 \mathrm{kPa}$ and a CSR of 0.3 , the hydraulic conductivities are $6.8 \times 10^{-8} \mathrm{~cm} / \mathrm{s}, 5.2 \times 10^{-8} \mathrm{~cm} / \mathrm{s}$, and $4.6 \times 10^{-8} \mathrm{~cm} / \mathrm{s}$ for $N$ values of $500,2,000$, and 5,000 , respectively.

(2) Axial deformation under coupled dynamic stress and seepage fields:

Axial deformation is attributed to the coupled dynamic stress field and seepage field. The axial deformation increases with increasing back pressure, CSR, and $N$. With an $N$ of 5,000, a CSR of 0.3 , and applied water pressure of $150 \mathrm{kPa}$, the axial deformation and cumulative strain exhibit maximum values of $3.82 \mathrm{~mm}$ and $4.78 \%$, respectively, which is an increase of $53.2 \%$ compared with a CSR of 0.1 .

With an $N$ of 5,000 and a CSR of 0.3 , the axial deformations are $1.46 \mathrm{~mm}, 1.47 \mathrm{~mm}, 2.33 \mathrm{~mm}$, and $3.82 \mathrm{~mm}$ for applied water pressures of $20 \mathrm{kPa}$, 


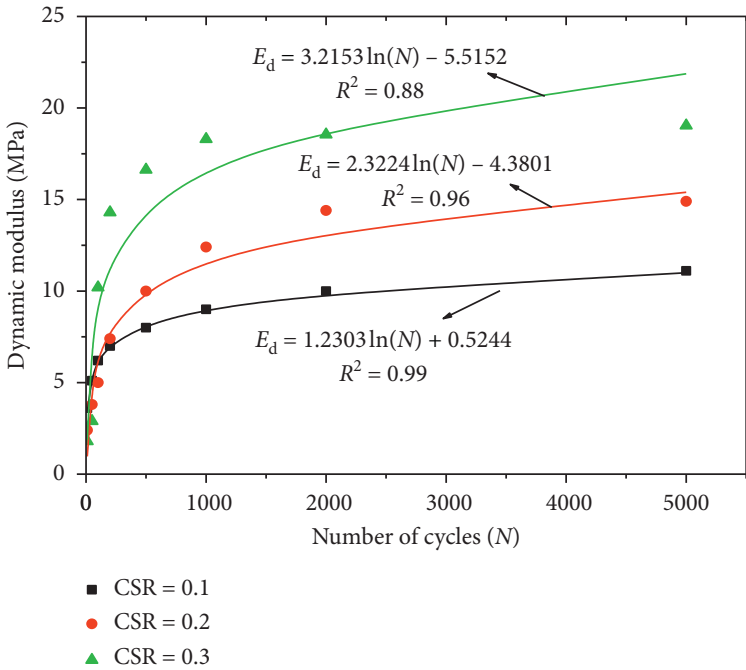

(a)

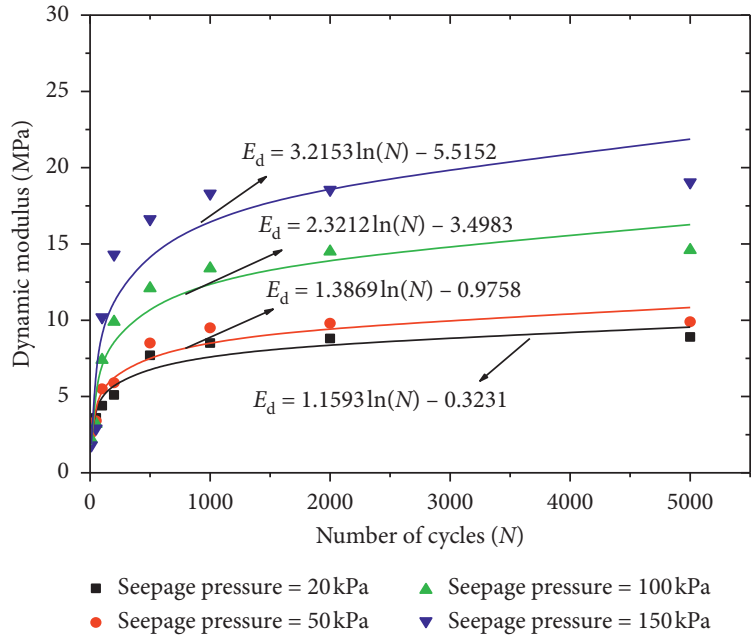

(b)

FIGURE 11: Variation in dynamic modulus with $N$ : (a) different CSR values; (b) different seepage pressures.

TABle 4: Parameters for the dynamic modulus equation under different CSRs and seepage pressures.

\begin{tabular}{|c|c|c|c|c|}
\hline Applied water pressure $(\mathrm{kPa})$ & CSR & $A$ & $B$ & $R^{2}$ \\
\hline \multirow{3}{*}{20} & 0.1 & 0.59 & 4.0672 & 0.92 \\
\hline & 0.2 & 0.9134 & 2.4834 & 0.98 \\
\hline & 0.3 & 1.1593 & -0.3231 & 0.91 \\
\hline \multirow{3}{*}{50} & 0.1 & 0.8779 & 2.3727 & 0.88 \\
\hline & 0.2 & 1.1448 & 1.1237 & 0.98 \\
\hline & 0.3 & 1.3869 & -0.9758 & 0.93 \\
\hline \multirow{3}{*}{100} & 0.1 & 0.9984 & 1.8141 & 0.98 \\
\hline & 0.2 & 1.7917 & -2.4588 & 0.95 \\
\hline & 0.3 & 2.3212 & -3.4983 & 0.92 \\
\hline \multirow{3}{*}{150} & 0.1 & 1.2303 & 0.5244 & 0.99 \\
\hline & 0.2 & 2.3224 & -4.3801 & 0.96 \\
\hline & 0.3 & 3.2153 & -5.5152 & 0.88 \\
\hline
\end{tabular}

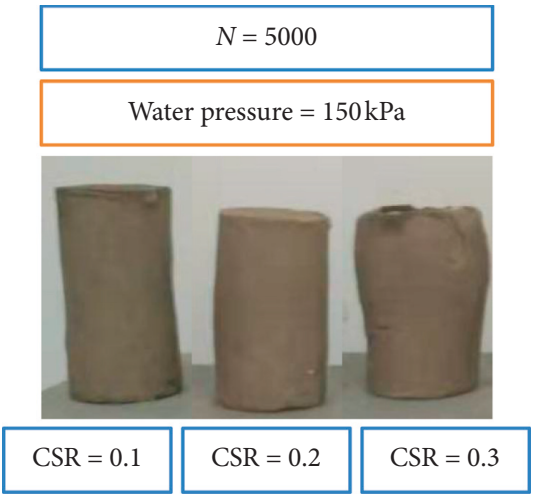

(a)

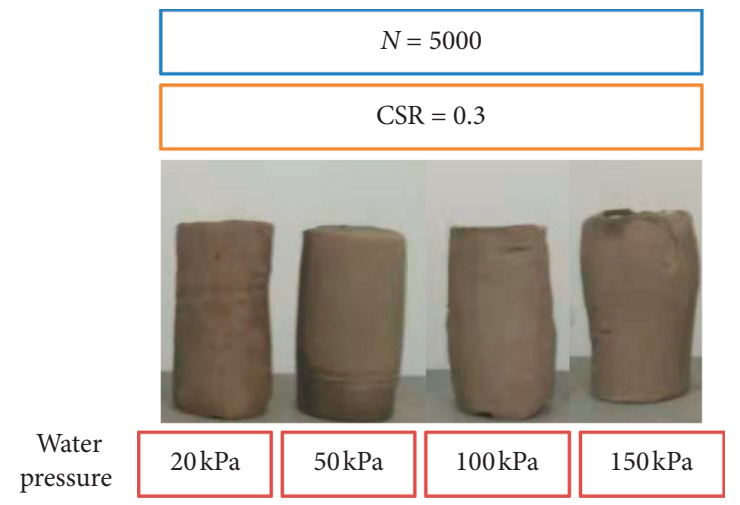

(b)

FIgURE 12: Failure mode of samples: (a) different CSRs; (b) different water pressures.

$50 \mathrm{kPa}, 100 \mathrm{kPa}$, and $150 \mathrm{kPa}$, respectively. With an applied water pressure of $150 \mathrm{kPa}$ and $N$ of 5,000 , the cumulative strains are $3.12 \%, 3.96 \%$, and $4.78 \%$ for
CSRs of $0.1,0.2$, and 0.3 , respectively. With a water pressure of $150 \mathrm{kPa}$ applied at the bottom of the specimen and CSR of 0.3 , the axial deformations 
reach $2.5 \mathrm{~mm}, 3.17 \mathrm{~mm}$, and $3.82 \mathrm{~mm}$ for $N$ values of $500,2,000$, and 5,000, respectively.

(3) Hysteresis curves and dynamic modulus:

The hysteresis curve gradually becomes denser or thinner with increasing $N$ and CSR, which is different from the dynamic characteristics of soft soil under undrained conditions. With a CSR of 0.3 , an $N$ of 5,000, and an applied water pressure of $150 \mathrm{kPa}$, the hysteresis curve approaches a straight line.

The dynamic modulus is related to $N$, CSR, and seepage pressure. In terms of different CSR values and seepage pressures, an empirical equation for the dynamic modulus is suggested: $E_{\mathrm{d}}=A \ln (N)+B$. This equation may be applied in engineering practice to help engineers predict the deformation of Tianjin clays under coupled dynamic stress and seepage fields.

\section{Data Availability}

The data used to support the findings of this study are available from the corresponding author upon request.

\section{Conflicts of Interest}

The authors declare that there are no conflicts of interest regarding the publication of this paper.

\section{Acknowledgments}

The authors acknowledge the National Key Research and Development Program of China (Grant no. 2017YFC0805402), National Natural Science Foundation of China (NSFC) (Grant no. 51578371), Open Project of State Key Laboratory of Disaster Reduction in Civil Engineering (Grant no. SLDRCE1701), and Tianjin Construction Commission Science and Technology Project (Grant no. 2017E6-0015) for their financial support.

\section{References}

[1] H. Lei, S. Feng, and Y. Jiang, "Geotechnical characteristics and consolidation properties of Tianjin marine clay," Geomechanics and Engineering, vol. 16, no. 2, pp. 125-140, 2018.

[2] L. Guo, J. Wang, Y. Cai, H. Liu, Y. Gao, and H. Sun, "Undrained deformation behavior of saturated soft clay under long-term cyclic loading," Soil Dynamics and Earthquake Engineering, vol. 50, no. 7, pp. 28-37, 2013.

[3] Y. Tang, K. Sun, X. Zheng, Q. Yang, and J. Zhou, “The deformation characteristics of saturated mucky clay under subway vehicle loads in Guangzhou," Environmental Earth Sciences, vol. 75, no. 5, pp. 1-10, 2016.

[4] X. Yang and R. Zhang, "Collapse analysis of shallow tunnel subjected to seepage in layered soils considering joined effects of settlement and dilation," Geomechanics and Engineering, vol. 13, no. 2, pp. 217-235, 2017.

[5] C.-L. Yan, Y.-Q. Tang, Y.-D. Wang, and X.-W. Ren, "Accumulated deformation characteristics of silty soil under the subway loading in Shanghai," Natural Hazards, vol. 62, no. 2, pp. 375-384, 2012.
[6] X. Bian, H. Jiang, and Y. Chen, "Accumulative deformation in railway track induced by high-speed traffic loading of the trains," Earthquake Engineering and Engineering Vibration, vol. 9, no. 3, pp. 319-326, 2010.

[7] L. Ma, L. Wang, Z. Guo, H. Jiang, and Y. Gao, "Time development of scour around pile groups in tidal currents," Ocean Engineering, vol. 163, pp. 400-418, 2018.

[8] Q. Yang, Y. Ren, J. Niu, K. Cheng, Y. Hu, and Y. Wang, "Characteristics of soft marine clay under cyclic loading: a review," Bulletin of Engineering Geology and the Environment, vol. 77, no. 3, pp. 1027-1046, 2018.

[9] H. Lei, J. Liu, M. Liu, Z. Zhang, and M. Jiang, "Effects of frequency and cyclic stress ratio on creep behavior of clay under cyclic loading," Marine Georesources \& Geotechnology, vol. 35, no. 2, pp. 281-291, 2017.

[10] Y. Zhao, X. Du, B. Xiong, and D. Zhang, "Experimental study on dynamic characteristics of marine soft clay in North China," Journal of Coastal Research, vol. 83, pp. 474-478, 2018.

[11] Y. Shen, W. Du, H. Liu, B. Wang, and Q. Wang, "Amplitude ratio effect on dynamic characteristics of remolded soft clay under train loads," Soil Mechanics and Foundation Engineering, vol. 55, no. 4, pp. 249-257, 2018.

[12] S. Pandya and A. Sachan, "Experimental studies on effect of load repetition on dynamic characteristics of saturated Ahmedabad cohesive soil," International Journal of Civil Engineering, pp. 1-12, 2019.

[13] Y. Miao, F. Zhou, J. Yin et al., "Effects of frequency and confining pressure on consolidation drainage behavior of soft marine clays," Marine Georesources and Geotechnology, pp. 1-9, 2018.

[14] E. Martínez, H. Patiño, and R. Galindo, "Evaluation of the risk of sudden failure of a cohesive soil subjected to cyclic loading," Soil Dynamics and Earthquake Engineering, vol. 92, pp. 419-432, 2017.

[15] L. Pan and J. Wang, "Effects of vibration frequency on relevant behavior of saturated soft clay," Journal of Nature Disasters, vol. 16, no. 16, pp. 204-208, 2007.

[16] K. Yasuhara, T. Yamanouchi, and K. Hirao, "Cyclic strength and deformation of normally consolidated clay," Soils and Foundations, vol. 22, no. 3, pp. 77-91, 1982.

[17] A. R. Mortezaie and M. Vucetic, "Effect of frequency and vertical stress on cyclic degradation and pore water pressure in clay in the NGI simple shear device," Journal of Geotechnical and Geoenvironmental Engineering, vol. 139, no. 10, pp. 1727-1737, 2013.

[18] X. Wang, "Research of accelerated creep properties and microscopic mechanism on soft clay," Master thesis, Tianjin University, Tianjin, China, 2014.

[19] H. Lei, B. Li, H. Lu, and Q. Ren, "Dynamic deformation behavior and cyclic degradation of ultra soft soil under cyclic loading," Journal of Materials in Civil Engineering, vol. 28, no. 11, article 04016135, 2016.

[20] H. Lei, M. Liu, W. Zhang, and B. Li, "Dynamic properties of reclaimed soft soil under the combined frequency cyclic loading," Road Materials and Pavement Design, vol. 18, no. 3, pp. 54-64, 2017.

[21] S. Fukushima and T. Ishii, "An experimental study of the influence of confining pressure on permeability coefficients of filldam core materials," Soils and Foundations, vol. 26, no. 4, pp. 32-46, 1986.

[22] J. Liang, "Experimental study on soft soil deformation and seepage characteristics with microscopic parameter analysis," Doctoral dissertation, South China University of Technology, Guangzhou, China, 2010. 
[23] D. Sun and Z. Xu, "Permeability of structural soft soils," Hydrogeology and Engineering Geology, vol. 39, no. 1, pp. 36-41, 2012.

[24] H. Bayesteh and A. A. Mirghasemi, "Numerical simulation of porosity and tortuosity effect on the permeability in clay: microstructural approach," Soils and Foundations, vol. 55, no. 5, pp. 1158-1170, 2015.

[25] L. Arpan and K. Sujit, "Effect of vertical pressure on horizontal and vertical permeability of soil and effect of surcharge pressure on 3D consolidation of soil," Advances in Civil Engineering, vol. 2018, Article ID 9591374, 11 pages, 2018.

[26] D. M. Muddle and K. M. Briggs, "Macropore structure and permeability of clay fill samples from a historic clay fill earthwork," Transportation Geotechnics, vol. 19, no. 6, pp. 96-109, 2019.

[27] S. Jia, "Hydro-mechanical coupled creep damage constitutive model of boom clay, back analysis of model parameters and its engineering application," Chinese Journal of Rock Mechanics and Engineering, vol. 28, no. 2, p. 2594, 2009.

[28] D. Zhong, X. Zhang, X. Ao, X. Wang, D. Tong, and B. Ren, "Study on coupled 3D seepage and stress fields of the complex channel project," Science China Technological Sciences, vol. 56, no. 8, pp. 1906-1914, 2013.

[29] Ministry of Water Resources of the People's Republic of China, Specification of Soil Test (SL237-1-1999), China Communications Press, Beijing, China, 1999.

[30] A. Cassagrande, "Research on the atterberg limits of soils," Public Roads, vol. 13, no. 3, pp. 121-136, 1932.

[31] J. Wang, L. Guo, Y. Cai, C. Xu, and C. Gu, "Strain and pore pressure development on soft marine clay in triaxial tests with a large number of cycles," Ocean Engineering, vol. 74, pp. 125-132, 2013.

[32] I. Idriss, R. Dobry, and R. Singh, "Nonlinear behavior of soft clays during cyclic loading," Journal of the Geotechnical Engineering Division, vol. 104, no. 12, pp. 1427-1447, 1978.

[33] G. Shi, Z. Liu, and Y. Li, "One-dimensional rheological consolidation of soft clay under cyclic loadings considering non-darcy flow," Rock and Soil Mechanics, vol. 39, pp. 521$528,2018$. 


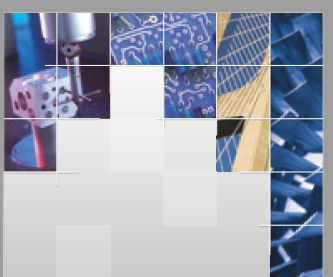

\section{Enfincering}
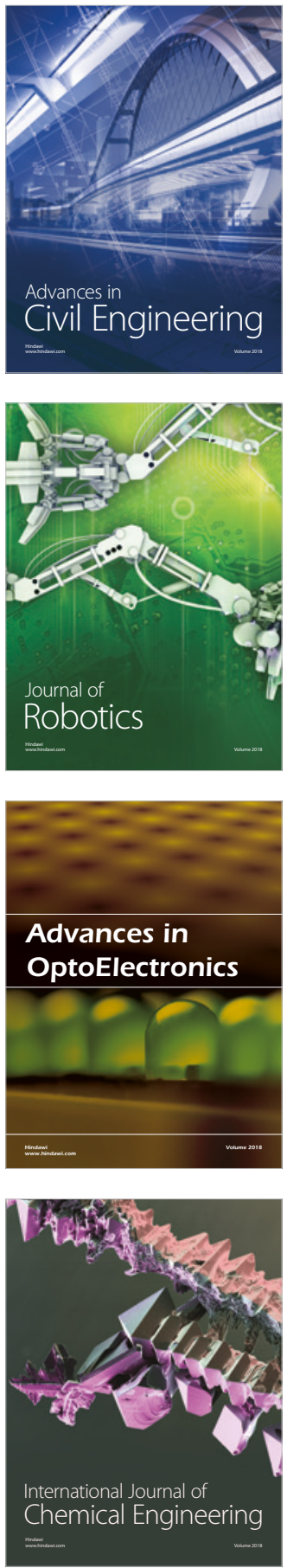

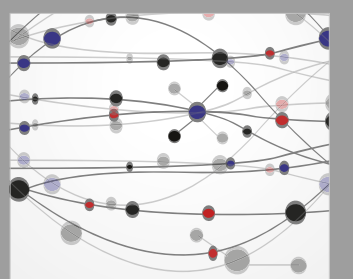

\section{Rotating \\ Machinery}

The Scientific World Journal

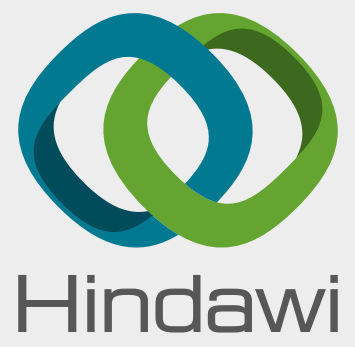

Submit your manuscripts at

www.hindawi.com
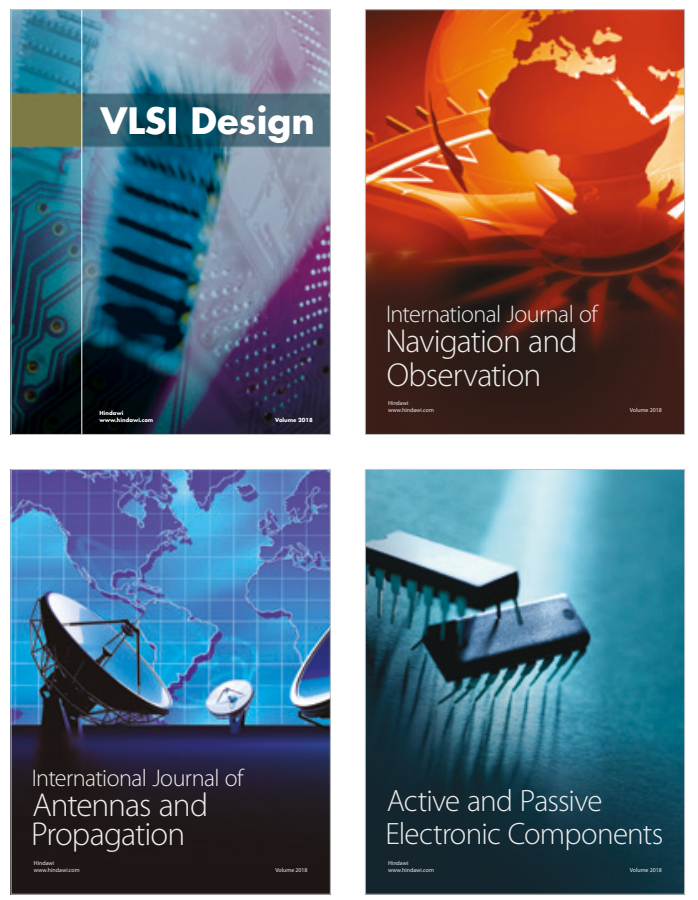
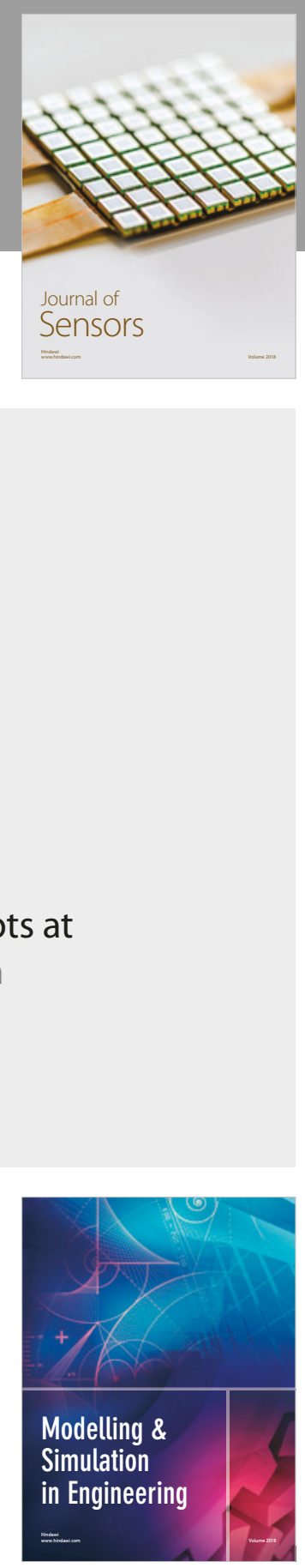

\section{Advances \\ Multimedia}
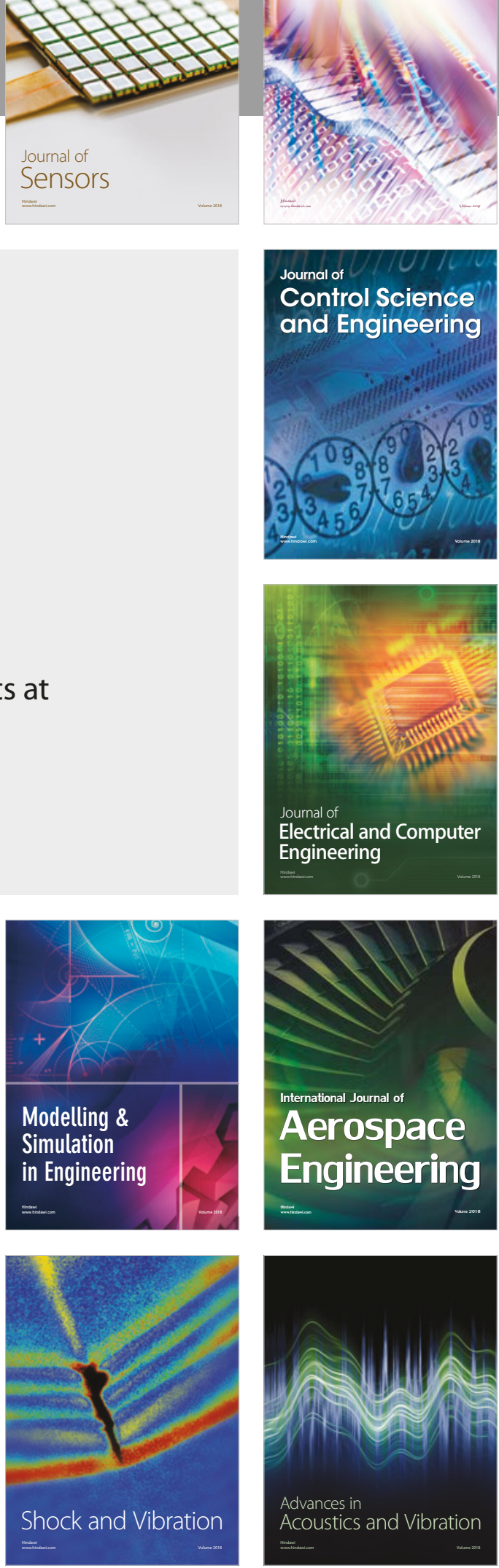